Al-Madrasah: Jurnal Ilmiah Pendidikan Madrasah Ibtidaiyah

Vol. 4, No. 2, 2020

DOI 10.35931/am.v4i2.316

P-ISSN: 2620-5807; E-ISSN: 2620-7184

\title{
BELAJAR SOSIAL: INTERRELASI ANTARA INDIVIDU, LINGKUNGAN, DAN PERILAKU DALAM PEMBELAJARAN FIQIH DI MI MIFTAHUL ANWAR DESA BANUA LAWAS
}

\author{
Hikmatu Ruwaida \\ Dosen PGMI STIQ Amuntai \\ e-mail: Ruwaida0212@gmail.com
}

\begin{abstract}
Abstrak
Mata pelajaran Fiqih di Madrasah Ibdtidaiyah bertujuan agar peserta didik dapat memahami pokok-pokok hukum Islam sebagai pedoman bagi kehidupan pribadi dan sosialnya. Peserta didik mempelajari tentang pemahaman tata cara pelaksanaan rukun Islam, pengamalan sederhana tata cara jual beli sesuai tuntunan syariat, makanan dan minuman yang halal dan haram, dan pembiasaannya dalam kehidupan sehari-hari. Pembiasaan menjadi fokus mata pelajaran Fiqih di Madrasah Ibtidaiyah, peserta didik diharapkan mampu mempraktikkan hukum syara yang bersifat amaliah dengan benar dalam kehidupan sehari-hari. Oleh karena itu, menjadi penting untuk mengenal anak didik dan cara memengaruhinya. Penelitian ini bertujuan untuk mendeskripsikan interrelasi individu, lingkungan dan perilaku dalam pembiasaan praktik hukum syara yang bersifat amaliah pada anak MI. Data dikumpulkan dengan wawancara, observasi dan dokumentasi. Kemudian data diorganisasikan, melakukan sintesis dan menghasilkan kesimpulan. Adapun hasil penelitian menujukkan bahwa untuk mendukung keberhasilan pembelajaran Fiqih di MI Miftahul Anwar, guru memadukan antara pemodelan, proses kognitif dan lingkungan belajar. Pemodelan melibatkan guru, orang tua dan melibatkan seluruh warga sekolah. Anak menjadi observator, mengamati sekaligus meniru tingkah laku lingkungan sekolahnya terutama dari gurunya. Dalam proses pengamatan anak melakukan proses kognitif, yang didukung oleh lingkungan sebagai penguat dari tingkah laku tersebut. Orang tua peserta didik sebagai penyokong keberhasilan pembelajaran Fiqih berperan sebagai motivator sekaligus model pula bagi anak. Dengan adanya relasi antara model, lingkungan belajar dan kognitif berupa keyakinan diri anak bahwa ia mampu dan harus berbuat sesuai dengan standar dalam ajaran agamanya, maka amaliah-amaliah yang dipelajari dalam Fiqih Madrasah Ibtidaiyah dapat terinternalisasi dalam diri peserta didik.
\end{abstract}

Kata Kunci: Belajar Sosial, Pembelajaran Fiqih, Madrasah Ibtidaiyah 
Hikmatu Ruwaida: Belajar Sosial: Interrelasi Antara Individu, Lingkungan, dan Perilaku Dalam Pembelajaran Fiqih di MI Miftahul Anwar Desa Banua Lawas

\section{A. Pendahuluan}

Pendidikan adalah salah satu cara untuk meningkatkan kualitas sumber daya manusia dan alat untuk membangun bangsa secara berkelanjutan. Jika pendidikan merupakan salah satu alat pengembang sumber daya manusia, maka guru sebagai salah satu unsur pokok di dalamnya memiliki tanggung jawab untuk mengatasi permasalahan, salah satu yang utama adalah persoalan yang muncul dalam pembelajaran. Belajar adalah suatu proses, melibatkan pengalaman yang melibatkan berbagai unsur di dalamnya baik itu jasmani maupun emosional peserta didik dan masing-masing komponen dalam pembelajaran akan saling mempengaruhi dalam mencapai tujuan pembelajaran. Anak akan berinteraksi dengan lingkungan sebagai upaya menuju perubahan tingkah lakunya. Dalam belajar, seseorang akan dipengaruhi berbagai faktor sehingga bagi pendidik penting untuk mengetahuinya agar mampu mengatur dan mengendalikan anak didiknya. Pendidikan dasar merupakan wadah peletak dasar-dasar keilmuan, mengembangkan segala potensi anak sekaligus mengoptimalkan perkembangan mereka melalui pembelajaran. Mata pelajaran Fiqih yang dipelajari di Madrasah Ibdtidaiyah bertujuan agar peserta didik dapat memahami pokok-pokok hukum Islam secara menyeluruh sebagai pedoman bagi kehidupan pribadi dan sosialnya. Peserta didik mempelajari tentang pemahaman tata cara pelaksanaan rukun Islam, pengamalan sederhana tata cara jual beli sesuai tuntunan syariat, makanan dan minuman yang halal dan haram, dan pembiasaannya dalam kehidupan sehari-hari. Pembiasaan inilah yang kemudian menjadi fokus pada mata pelajaran Fiqih di Madrasah Ibtidaiyah, dimana anak tidak hanya mengenal, tapi diharapkan mampu mempraktikkan hukum syara yang bersifat amaliah dengan benar dalam kehidupan sehari-hari. Oleh karena itu, menjadi penting untuk mengenal anak didik dan bagaimana cara memengaruhinya, yang tentunya pendidik harus mengetahui berbagai teori belajar dan pembelajaran yang dikemukakan oleh beberapa ahli, salah satunya adalah teori belajar sosial yang dipelopori oleh Albert Bandura.

Albert Bandura merupakan pelopor teori pembelajaran sosial (Social Learning Theory), salah satu konsep dalam teori behaviorisme yaitu belajar melibatkan kognitif yang terdiri dari fikiran, pemahaman dan evaluasi. Konsep yang populer dari Albert Bandura adalah belajar sosial dengan diperkuat melalui keyakinan dari dalam diri individu tersebut 
Hikmatu Ruwaida: Belajar Sosial: Interrelasi Antara Individu, Lingkungan, dan Perilaku Dalam Pembelajaran Fiqih di MI Miftahul Anwar Desa Banua Lawas

untuk berhasil melakukan sesuatu atau disebut dengan efikasi diri. Eksperimen yang dilakukan adalah eksperimen boneka bobo atau disebut Bobo Doll yang menunjukkan anak-anak megulang perilaku orang dewasa disekitarnya. Anak terutama pada usia sekolah dasar merupakan sosok peniru ulung. Ia akan mencontoh apapun di sekitarnya yang dianggapnya baik dan menarik baginya. Dalam psikologi perkembangan dikatakan pula anak pada tahap ini memang berada pada tahap konkret operasional, yang mana kemampuan kognitif, afektif, psikomotorik akan lebih mudah melekat dalam struktur berpikirnya jika dilakukan dengan modelling. Perilaku anak akan dipengaruhi oleh faktor sosial atau lingkungannya. Oleh karena itu, teori belajar sosial (social learning theory) yang dikemukakan oleh Albert Bandura menyatakan bahwa faktor lingkungan belajar, perilaku yang direpetisi dari contoh yang ia lihat, dan faktor dari dalam dirinya berupa keyakinan akan keberhasilan dalam melakukan sesuatu merupakan hal penting dalam pembelajaran. Menurutnya ketika anak belajar, mereka dapat mereprensentasikan apa yang sudah dipelajarinya dalam bentuk perilaku.

\section{B. Metode Penelitian}

Jika ditinjau dari sudut pandang bidang keilmuan, penelitian ini merupakan penelitian kualitatif tentang praktek pendidikan (field research). Penelitian pendidikan merupakan penelitian yang digunakan untuk mendapatkan informasi yang berguna dan dapat dipertanggungjawabkan mengenai proses kependidikan. Jenis Penelitian ini adalah penelitian kualitatif. Penelitian kualitatif adalah suatu proses mencari data-data dari permasalahan berdasarkan atas tradisi keilmuan metodologis yang jelas yang berlatar fenomena lingkungan sosial maupun manusia. Peneliti fenomena secara menyeluruh, menganalisis informasi yang diperoleh dan melaporkan pandangan-pandangan informan yang ada dalam konteks penelitian secara alamiah. ${ }^{1}$ Infomasi yang digali dimaksudkan untuk memahami fenomena yang dialami oleh subjek penelitian dalam bentuk perilaku, persepsi, tindakan dan lain-lain secara menyeluruh kemudian dijelaskan dalam bentuk kata-kata yang

${ }^{1}$ Rulam Ahmadi, Metode Penelitian Kualitatif, (Yogyakarta: Ar-Ruzz Media, 2014), h. 16. 
Hikmatu Ruwaida: Belajar Sosial: Interrelasi Antara Individu, Lingkungan, dan Perilaku Dalam Pembelajaran Fiqih di MI Miftahul Anwar Desa Banua Lawas

menggambarkan secara alamiah tentang informasi tersebut. ${ }^{2}$ Dalam pengumpulan data, peneliti menghimpun data secara empiris. Dari data tersebut dimaksudkan untuk memahami ragam kegiatan yang dikembangkan menjadi suatu pola temuan peneliti, pola temuan tersebut selanjutnya diverifikasikan dengan menguji kebenarannya bertolak pada data baru yang spesifik. Pengumpulan data dilakukan melalui wawancara, observasi dan dokumentasi. Kemudian data diorganisasikan, melakukan sintesis dan menghasilkan kesimpulan. ${ }^{3}$

\section{Pembahasan}

Edward L. Thorndike yang pertama kali berusaha meneliti belajar observasional secara eksperimental, pada tahun 1898, dia meletakkan seekor kucing ke dalam kotak teka-teki dan kucing lainnya disangkar yang ada di dekatnya. Kucing di kotak teka-teki sudah belajar bagaimana cara keluar sehingga tugas kucing kedua hanya perlu mengamati kucing pertama untuk meniru bagaimana cara membebaskan diri atau keluar dari kotak teka-teki tersebut. Ia kemudian memasukkan kucing kedua ke dalam kotak teka-teki, tetapi kucing kedua ternyata tidak memberikan respons membebaskan diri. Kemudian Thorndike melakukan percobaan serupa dengan subjek ayam dan anjing dengan hasil yang sama pula. Berapa pun lamanya hewan melihat hewan lain yang lebih pintar, tampaknya hewan tidak mau mempelajari apa pun. Pada tahun 1901, Thorndike melakukan percobaan terhadap monyet, tetapi kembali dengan hasil sama sehingga ia berkesimpulan bahwa tidak ada yang mendukung hipotesis bahwa mereka memiliki kemampuan untuk belajar melakukan sesuatu setelah melakukan hewan lain melakukannya. ${ }^{4}$ Oleh karena itu, Thorndike menganggap bahwa belajar bukanlah hasil dari meniru, akan tetapi lebih kepada proses trial and error (uji coba) yang berproses melalui interaksi dengan lingkungannya dan akan terwujud dalam serangkaian respon yang kompleks sebelum sampai pada pemecahan problem.

${ }^{2}$ Lexy J. Moeleong, Metode Penelitian Kualitatif, (Bandung: Remaja Rosdakarya, 2005), h. 6.

${ }^{3}$ Sugiyono, Metode Penelitian Kuantitatif Kualitatif dan R\&D, (Bandung: Alfabeta, 2012), h. 249-253

${ }^{4}$ Hergenhahn dan Matthew H. Olson. Theories of Learning (Teori Belajar) Theories of Learning (Teori Belajar), terj. TriwibowoB.S, (Jakarta: Kencana, 2008), h. 357. 
Hikmatu Ruwaida: Belajar Sosial: Interrelasi Antara Individu, Lingkungan, dan Perilaku Dalam Pembelajaran Fiqih di MI Miftahul Anwar Desa Banua Lawas

Pada tahun 1908, J. B. Watson mereplikasi riset Thorndike dengan monyet, yang kemudian ia juga tidak menemukan adanya belajar observasional sehingga Thorndike dan Watson sama-sama menyimpulkan bahwa belajar hanya berasal dari direct experience (pengalaman langsung) bukan dari vicarious experience (pengalaman tak langsung atau pengganti) yang dengan kata lain mereka menyimpulkan bahwa belajar adalah hasil interaksi seseorang dengan lingkungannya dan bukan hasil dari pengamatan terhadap interaksi orang lain. ${ }^{5}$ Oleh karena itu, belajar menurut mereka lebih kepada proses untuk mencapai tujuan, ada suatu prosedur atau langkah yang harus dilalui seseorang untuk sampai pada tujuan belajar sehingga dalam literatur-literatur yang ada, pengertian belajar merupakan proses perubahan perilaku sebagai hasil hubungan timbal balik dengan lingkungannya.

Senada pula dengan apa yang dikatakan oleh Oemar Hamalik dalam bukunya Proses Belajar Mengajar bahwa belajar sebenarnya merupakan proses pengalaman, yang mana pengalaman juga terbagi menjadi dua bagian, yang menurut Oemar Hamalik ada yang disebut dengan pengalaman langsung partisipasi sesungguhnya, berbuat dan sebagainya, ada pula pengalaman pengganti yakni melalui observasi langsung (melihat kejadian-kejadian aktual, melihat drama dan pantomimik), melalui gambar, melalui grafis, melalui kata-kata (membaca, mendengar), dan melalui simbol-simbol (terminologi, rumusrumus, dan lain-lain). ${ }^{6}$

Miller dan Dollard juga menjelaskan bahwa imitasi menjadi kebiasaan. Seperti yang dicontohkan pada perilaku si adik yang belajar meniru perbuatan kakaknya akan membawanya pada penguatan, yang mana Miller dan Dollard menyebut tendensi untuk meniru perilaku ini sebagai generalized imitation (imitasi atau perilaku yang digeneralisasikan). ${ }^{7}$ Menurut mereka peran model adalah memandu respon pengamat sampai respon yang tepat diberikan atau untuk menunjukkan kepada pengamat respon mana yang akan diperkuat dalam situasi tertentu. Jika respon tidak diberikan dan diperkuat, maka menurut mereka bukan disebut belajar. Belajar imitatif adalah hasil dari observasi,

\footnotetext{
${ }^{5}$ Hergenhahn dan Matthew H. Olson. Theories of Learning (Teori Belajar), h. 357.

${ }^{6}$ Oemar Hamalik, Proses Belajar Mengajar, (Bandung: Remaja Rosdakarya, 2013), h. 29-30.

${ }^{7}$ Hergenhahn dan Matthew H. Olson. Theories of Learning (Teori Belajar), terj. TriwibowoB.S, (Jakarta: Kencana, 2008), h. 358.
} 
Hikmatu Ruwaida: Belajar Sosial: Interrelasi Antara Individu, Lingkungan, dan Perilaku Dalam Pembelajaran Fiqih di MI Miftahul Anwar Desa Banua Lawas

respon nyata dan penguatan. Dalam hal ini, Ibu Norniah selaku guru Fiqih di MI Miftahul Anwar mengatakan bahwa:

Semua guru di sekolah ini berupaya untuk menjadi teladan yang baik bagi anak didik, terutama guru-guru pada rumpun mata pelajaran pendidikan agama Islam. Di sini saya sekalipun mengajar Fiqih, saya tetap berusaha agar anak-anak tetap berperilaku sebagaimana yang diajarkan dalam hukum Islam, dalam hukum-hukum Fiqih pun tentunya tetap ada materi-materi yang berkaitan dengan perilaku terutama terkait dengan amaliah sehari-hari. Misalnya thaharah, bukan hanya mengajarkan tentang wudhu, tayammum dan mandi, saya juga mengajarkan kepada anak pentingnya hidup bersih, baik bersih dari pakaian dan lingkungan terutama lingkungan belajar. ${ }^{8}$

Maka dalam hal ini, anak menjadi observator, mengamati sekaligus meniru tingkah laku lingkungan sekolahnya terutama dari gurunya. Dalam proses pengamatan ini anak akan melakukan proses kognitif, yang harus didukung oleh lingkungan sebagai penguat dari tingkah laku tersebut.

Salah satu teori belajar sosial yang dikemukakan oleh Albert Bandura juga adalah teori kognitif sosial. Albert Bandura mengembangkan satu versi pandangan behaviorisme pada awal 1960-an yang awalnya bernama aliran "sosiobehaviorisme" dan kemudian menjadi teori kognitif sosial. Tingkah laku tidak selalu harus diperkuat secara langsung agar muncul, kita dapat belajar dengan mengamati orang lain dan melihat akibat tindakan mereka. ${ }^{9}$

Teori kognitif sosial (social kognitif theory) menjelaskan bahwa faktor sosial dan kognitif berperan penting dalam pembelajaran. Faktor kognitif dapat beru[a harapan atau keyakinan anak didik terhadap keberhasilannya dalam belajar dan faktor sosial bisa berupa hasil observasi anak didik terhadap lingkungan belajarnya misalnya orang tua sebagai rool model dalam perilaku belajarnya. Albert Bandura adalah salah satu perancang utama teori kognitif sosial. Bandura mengemukakan ketika siswa belajar, mereka dapat merepresentasikan atau mentransformasi pengalaman mereka secara kognitif. Dalam pengkondisian operan juga dikatakan bahwa hubungan terjadi hanya

\footnotetext{
${ }^{8}$ Wawancara dengan Ibu Norniah Pada Tanggal 12 Nopember 2019

${ }^{9}$ Nigel C. Benson dan Simon Grove, Psikologi For Beginners, terj. Medina Chodijah, (Bandung: Mizan, 2000), h. 89.
} 
Hikmatu Ruwaida: Belajar Sosial: Interrelasi Antara Individu, Lingkungan, dan Perilaku Dalam Pembelajaran Fiqih di MI Miftahul Anwar Desa Banua Lawas

antara pengalaman lingkungan dan perilaku. ${ }^{10}$ Oleh karena itu, Bandura mengatakan bahwa perilaku sosial, kognitif dan person akan mempengaruhi perilaku. Hal inilah yang disebut model determinisme respirokal yang terdiri dari tiga faktor utama dalam belajar yaitu perilaku, person atau kognitif, dan lingkungan.

Dalam hal ini, Ibu Norniah selaku guru Fiqih di MI Miftahul Anwar mengatakan bahwa :

Oleh karena mata pelajaran yang saya ajarkan adalah Fiqih, yang semua kita tahu bahwa Fikih ini berkaitan dengan ibadah-ibadah amaliah sehari-hari, maka peserta didik kelihatan lebih semangat mempelajarinya, hal ini didukung oleh faktor orang tua yang ingin anaknya bisa berwudhu, shalat dan ibadah-ibadah lain dengan benar. Selain itu, sekolah ini juga memiliki TPA yang secara tidak langsung juga memudahkan saya mengajarkan Fikih kepada anak-anak. Jadi faktor dari peserta didik sendiri dan lingkungannya memang mendukung mata pelajaran yang saya ampu di sekolah ini. ${ }^{11}$

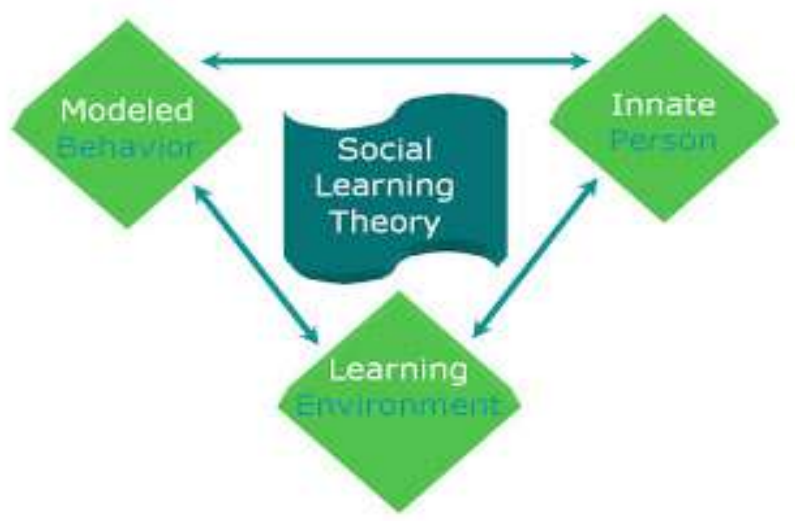

Dari skema di atas di jelaskan bahwa antara lingkungan belajar (learning environment), tingkah laku (model behaviour) dan individu (kognitif) sendiri sama-sama saling mempengaruhi satu sama lain. Faktor-faktor ini yang akan saling memengaruhi proses belajar.

\footnotetext{
${ }^{10}$ John W. Santrock., Psikologi Pendidikan, terj. Tri Wibowo B.S., (Jakarta: Kencana, 2010), h. 285.

${ }^{11}$ Wawancara dengan Ibu Norniah Pada Tanggal 12 Nopember 2019
} 
Hikmatu Ruwaida: Belajar Sosial: Interrelasi Antara Individu, Lingkungan, dan Perilaku Dalam Pembelajaran Fiqih di MI Miftahul Anwar Desa Banua Lawas

Belajar sosial menurut Bandura adalah adanya aktor person (kognitif) yang sangat mempengaruhi keberhasilan belajar anak didik, yang disebutnya self-efficacy, yakni keyakinan bahwa seseorang bisa mencapai keberhasilan dan memperoleh hasil yang baik sesuai dengan harapannya. Self-efficacy ini berpengaruh besar terhadap perilaku. ${ }^{12}$

Dalam hal ini, Ibu Norniah selaku guru Fiqih di MI Miftahul Anwar mengatakan bahwa :

Perihal motivasi anak, saya dibantu oleh orang tua siswa dan lingkungan di sekitar. Alhamdulillah di sini orangtua memiliki semangat yang tinggi terhadap pendidikan agama anak. Anak-anak usia madrasah ibtidaiyah ini memang harus ada dorongan motivasi dari luar dulu kemudian akan tumbuh menjadi kebiasaan. Pada saat mengajar biasanya saya menekankan tentang manfaat-manfaat yang didapatkan dengan mengamalkan kewajiban sesuai dengan syariat secara ilmiah dulu yang dekat dengan lingkungan anak seperti thaharah dikaitkan dengan kebersihan, kemudian saya menjelaskan bahwa dalam Islam ada balasan atau pahala dari mengerjakan perintah Allah yang tentunya dengan bahasa sederhana yang disesuaikan dengan perkembangan kognitif dan moral anak.

Dalam hal ini, self-efficacy merupakan sejenis dorongan positif pada diri seseorang yang membuatnya yakin bahwa ia dapat mengerjakan dan mendapatkan hasil yang optimal dari apa yang dilakukannya. Hal ini sangat bermanfaat bagi siswa dalam proses belajar sebab dengan adanya dorongan dan pemikiran positif tersebut, siswa akan mampu memandunya memperoleh pengalaman yang optimal.

\section{Pandangan Bandura Terhadap Belajar Observasional (Observasional Learning Theory)}

Pembelajaran observasional disebut juga meniru atau modelling adalah pembelajaran yang dilakukan ketika seseorang mengamati dan meniru pola orang lain atau bisa juga hal ini disebut dengan belajar melalui pengamatan. Pada tahun 1960-an, dikatakan bahwa penelitian mengenai minat belajar akan dirangsang dalam belajar observasional, di mana seorang individu belajar perilaku dengan melihat perilaku orang lain (model) yang melakukannya. Pada awalnya, riset mengenai belajar observasional dilakukan pada berbagai macam hewan dan didemonstrasikan oleh hewan seperti kuda, burung dara, tikus dan lainlain. ${ }^{13}$ Pada perkembangan selanjutnya, riset mengenai pembelajaran

\footnotetext{
${ }^{12}$ John W. Santrock., Psikologi Pendidikan, h. 286.

${ }^{13}$ Lester m. Sdorow dan Cheryl A. Rickabaugh, Psychology, (New York: McGraw-Hill, 2002), h. 237.
} 
Hikmatu Ruwaida: Belajar Sosial: Interrelasi Antara Individu, Lingkungan, dan Perilaku Dalam Pembelajaran Fiqih di MI Miftahul Anwar Desa Banua Lawas

observasional dilakukan pada manusia sebagaimana yang dinyatakan oleh Lester m. Sdorow dan Cheryl A. Rickabaugh dalam bukunya Psychology yaitu sebagai berikut.

There are numerous example of human observational learning. A few examples include infants learning to perform tasks after observing other infants perform them (Hanna \& Meltzoff, 1993), ballet dancers learning to perform dance sequences they have seen (Gray et al., 1991), and students learning to behave properly by observing other students doing so (Hallenbeck \& Kauffman, 1995).

Dari beberapa riset tersebut dijelaskan bahwa individu atau kelompok banyak belajar melalui observasi terhadap tindakan orang lain. Terminologi yang terkenal dalam teori belajar sosial adalah modelling. Modelling bukan hanya meniru tindakan model, tetapi modelling bisa juga dengan melakukan modifikasi tingkah laku yang diamati dan menggeneralisir berbagai pengamatan. Proses memodifikasi dan menggeneralisir tindakan inilah yang melibatkan proses kognitif, dimana seseorang memerlukan pengetahuan guna memproses informasi seperti mengingat, memahami, menganalisis, mensintesis, sampai pada mengevaluasi.

Bandura menekankan bahwa kondisi lingkungan dapat memberikan dan memelihara respon-respon tertentu pada diri seseorang. Asumsi dasar dari teori ini yaitu sebagian besar tingkah laku individu diperoleh dari hasil belajar melalui pengamatan atas tingkah laku yang ditampilkan oleh individu-individu lain yang menjadi model. Dapat dilihat dari hasil eksperimennya bahwa orang belajar banyak perilaku melalui peniruan, bahkan tanpa adanya penguat (reinforcement) sekalipun yang diterima. Kita bisa meniru beberapa perilaku hanya melalui pengamatan terhadap perilaku model, dan akibat yang ditimbulkannya atas model tersebut.

\section{Interrelasi Individu, Lingkungan, Dan Perilaku}

Pandangan Bandura berbeda dengan pandangan para ahli sebelumnya tentang belajar observasional. Bandura membedakan antara imitasi dan belajar observasional. Individu yang sedang belajar, mungkin melakukan imitasi, mungkin juga tidak melakukan imitasi. Bandura menyatakan bahwa apa yang dipelajari merupakan informasi. Kita belajar berdasar informasi demi kebaikan kita. Poin final dari belajar menurut Bandura adalah motivasi. Belajar observasional terjadi secara independen dari penguatan. Secara spesifik Bandura memiliki 4 proses, 
Hikmatu Ruwaida: Belajar Sosial: Interrelasi Antara Individu, Lingkungan, dan Perilaku Dalam Pembelajaran Fiqih di MI Miftahul Anwar Desa Banua Lawas

yaitu atensional, retensional, pembentukan perilaku/reproduksi dan motivasional.

\section{Proses Atensional}

Proses atensional atau proses memperhatikan dipelajari dari model yang diperhatikan. Belajar menurut Bandura merupakan proses yang terus berlangsung dan hanya model yang diamati saja yang dapat dipelajari. Oleh sebab itu, sebelum siswa memperoleh hasil belajar maka ia mengamati terlebih dahulu apa yang dilakukan oleh model. Karakteristik tersebut dalam beberapa bagian. Sesuatu itu diperhatikan karena pertama adanya kapasitas sensoris. Perbedaan kapasitas sensoris akan menentukan respon dari rangsangan model yang diberikan. Rangsangan model untuk orang tuna netra tentunya berbeda dengan rangsangan model yang diberikan pada orang tuna rungu agar respon yang diberikan sesuai dengan yang diharapkan. Kedua, respon yang diberikan oleh pengamat akan dipengaruhi oleh pengalaman belajar sebelumnya. Jika respon yang telah dilakukan di masa lalu terbukti mendapatkan suatu penguatan, maka perilaku yang sama akan diperhatikan pada situasi modeling berikutnya. Penguatan sebelumnya dapat menciptakan tata situasi perseptual dalam diri pengamat pada observasi berikutnya. Ketiga, karakteristik yang ditiru (model mempengaruhi respon pengamat. Riset menunjukkan bahwa model akan diperhatikan tergantung posisinya dimata observer seperti orang yang dihormati atau memiliki status tinggi, dianggap memiliki kemampuan lebih, dianggap kuat, dan dianggap atraktif. Sehubungan dengan hal ini, guru sebagai model dianggap figur yang mulia dimata anak didik sehingga mereka berusaha untuk mencontoh apa yang dikatakan dan dilakukan gurunya. ${ }^{14}$

Proses atensional ini berkaitan dengan motivasi peserta didik. Motivasi ini akan mempengaruhi perhatian anak terhadap pelajaran. Oleh karena itu, respon dan perhatian anak terhadap sesuatu tergantung dari minat dan motivasinya. Semakin tinggi minat dan motivasi anak terhadap sesuatu maka semakin ia akan semakin tertarik terhadap suatu hal, sebaliknya semakin tidak adanya kebutuhan dan minatnya terhadap suatu hal maka perhatiannya akan semakin rendah. Sehubungan dengan ini, guru Fiqih di MI Miftahul Anwar berusaha untuk menanamkan pentingnya melakukan ibadah dengan benar, berupa penjelasan tentang

\footnotetext{
${ }^{14}$ John W. Santrock, Psikologi Pendidikan, h. 287.
} 
Hikmatu Ruwaida: Belajar Sosial: Interrelasi Antara Individu, Lingkungan, dan Perilaku Dalam Pembelajaran Fiqih di MI Miftahul Anwar Desa Banua Lawas

reward dan punishment dalam ajaran Islam yang bisa diterima anak didik, bahwa mereka boleh bercita-cita untuk menjadi apapun tetapi juga harus melakukan ibadah sehari-hari dengan baik dan benar.

\section{Proses Retensional}

Untuk menggambarkan kembali tindakan model, seseorang harus mengidentifikasi informasi dan menyimpannya dalam ingatan sehingga informasi tersebut bisa direcall saat dibutuhkan. Penjelasan verbal secara sederhana atau berupa gambar-gambar maupun simbol yang menarik dari apa yang dilakukan model akan bisa membantu daya retensi seseorang terutama bagi siswa. Retensi siswa akan meningkat jika seorang guru dapat menggambarkan contoh secara hidup dan jelas. ${ }^{15}$

Hal tersebut juga terkait dengan psikologi perkembangan siswa pada tingkat dasar yakni mereka berada dalam tahap konkret operasional, yang mana anak dalam perkembangan ini lebih cendeung menyukai sesuatu yang bersifat contoh dan gambar sehingga informasi yang ia dapatkan menjadi mudah untuk disimpan dan diproduksi kembali jika diperlukan.

Informasi yang telah diperoleh dari observasi harus diingat dan disimpan agar sewaktu-waktu dapat dimanfaatkan. Menurut Bandura, pengetahuan yang diiperoleh siswa dapat disimpan melalui dua cara, yaitu secara imajinatif dan secara verbal. ${ }^{16}$ Simbolisasi verbal sebagaimana telah disebutkan seperti deskripsi verbal sederhana atau gambar yang menarik dan hidup yang dapat menarik perhatian siswa. Setelah informasi disimpan secara kognitif, ia dapat diulangi dan diperkuat sesudah belajar observasional terjadi. Menurut Bandura, peningkatan kapasitas simbolisasi inilah yang memampukan manusia untuk mempelajari banyak perilaku melalui observasi. Oleh sebab itulah, setiap informasi yang diperoleh kemudian disimpan dalam memori akan dapat dipergunakan kembali jika diperlukan, walaupun terkadang seseorang mengalami lupa sebab informasi yang lama telah diganti dengan informasi baru. Dalam ha ini Ibu Norniah menyatakan bahwa dalam menyerap pelajaran Fiqih tentang hukum-hukum yang berkaitan dengan amaliah sehari-hari, siswa di MI Miftahul Anwar memang perlu diingatkan dan dicontohkan secara terus-menerus baik itu melalui penyampaian secara verbal maupun dibuat dalam bentuk peraturan di

\footnotetext{
${ }^{15}$ John W. Santrock, Psikologi Pendidikan, h. 288.

${ }^{16}$ Hergenhahn dan Matthew H. Olson. Theories of Learning (Teori Belajar), h. 364.
} 
Hikmatu Ruwaida: Belajar Sosial: Interrelasi Antara Individu, Lingkungan, dan Perilaku Dalam Pembelajaran Fiqih di MI Miftahul Anwar Desa Banua Lawas

sekolah sehingga bisa menjadi sebuah kebiasaan islami yang melekat pada diri siswa MI Miftahul Anwar. Seluruh guru dan tenaga kependidikan di MI iftahul Anwar diupayakan mampu menjadi model untuk setiap siswa sehingga mereka tidak mengalami krisis belajar dari model anya karena perlikau yang menyimpang dari arga sekolah.

\section{Proses Pembentukan Perilaku}

Behavioral production process (proses pembentukan perilaku) akan memperlihatkan pengetahuan yang diperoleh dan bentuk manifestasinya dalam perilaku. Namun ada keterbatasan dalam menujukkan perilaku tersebut. Seseorang yang memiliki kemampuan fisik dan psikis yang lengkap tentu akan memberikan respon yang tepat. Oleh sebab itu dibutuhkan latihan secara berkelanjutan agar perilaku pengamat sama dengan perilaku model yang anak contoh. Perilaku yang ditampilkan oleh model akan menjadi contoh atau standar bagi perilaku pengamat. Oleh sebab itu pengamat akan menjadikan perilaku model menjadi standar acuan perilaku yang dilakukannya. Disinilah fungsi guru agar menjadi contoh yang baik untuk anak didiknya. Jadi retensi akan menciptakan "umpan balik" yang dapat dipakai sebagai upaya untuk menyamakan perilaku seseorang dengan perilaku model melalui observasi diri dan koreksi diri. Proses pembentukan perilaku inilah yang dalam Fiqih MI hendaknya ibadah-ibadah maupun muamalah ditanamkan melalui proses habit atau proses pembiasaan sehingga perilaku yang hadirpun tidak karena paksaan, tapi memang lahir dari kebiasaan mereka.

\section{Proses Motivasional}

Perilaku manusia ditimbulkan atau dimulai dari motivasi. Motivasi adalah keadaan dalam pribadi seseorang yang mendorng keinginan individu untuk melakukan kegiatan-kegiatan tertentu guna mencapai suatu tujuan. Motivasi yang ada pada seseorang akan mewujudkan suatu perilaku yang diarahkan pada tujuan mencapai sasaran. ${ }^{17}$

A motivation is a condition that energizes behavior and gives direction. One theory that directly links the more basics motives with

\footnotetext{
${ }^{17}$ M. Nur Ghufron dan Rini Risnawita S., Teori-teori Psikologi, (Yogyakarta: ArRuzz Media, 2014), h. 83.
} 
Hikmatu Ruwaida: Belajar Sosial: Interrelasi Antara Individu, Lingkungan, dan Perilaku Dalam Pembelajaran Fiqih di MI Miftahul Anwar Desa Banua Lawas

higher-order motives is that Abraham Maslow. Maslow argues that there is a hierarchy of needs ranging from basic physiological need such as hunger and thirst, to higher-order needs to be loved by others, to achieve and be recognized for one's achievements, to understand and explore, to enjoy art, music and beauty and finally to realize one's full potential. ${ }^{18}$

Setiap individu memiliki motivasi dalam melakukan sesuatu. Motivasi tersebut akan dimanfaatkan pada situasi tertentu. Motivasi pada diri individu tersebut menurut Bandura karena adanya penguatan dari apa yang pernah didapat dari model. Penguatan memiliki dua fungsi. Pertama, penguatan atau umpan balik akan menciptakan persepsi dalam diri pengamat bahwa jika mereka bertindak seperti yang dilakukan model untuk kegiatan tertentu, maka kemungkinan pengamat untuk melakukan kegiatan itu kembali, disebut sebagai fungsi informasional. Kedua, penguatan tersebut menjelaskan fungsi aktvitas tersebut, hal ini disebut motivational processes (proses motivasional). ${ }^{19}$ Jadi apa yang telah dipelajari individu melalui observasi akan tetap tersimpan sampai ia punya alasan untuk menggunakannya pada situasi tertentu.

Dari keempat proses yang meliputi atensi, retensi, produksi, dan motivasi tersebut, dikategorikan bahwa orang, lingkungan, dan perilaku seseorang merupakan sesuatu yang saling mendukung dalam menghasilkan perilaku selanjutnya. Perilaku seseorang tidak dapat dilihat dari satu posisi saja, melainkan harus memperhatikan ketiga posisi tersebut. Posisi yang saling mendukung tersebut dikenal dengan istilah reciprocal determinism (determinisme resiprokal) yang menjelaskan bahwa dalam sistem pembentukan perilaku seseorang akan dipengaruhi oleh beberapa faktor yang akan saling mempengaruhi yakni lingkungan belajar (learning environment), tingkah laku (model behaviour) dan individu (kognitif). Di MI Miftahul Anwar, pelajaran Fiqih ini sebagaimana keterangan dari guru Fiqih dan diperkuat dengan hasil observasi di lapangan bahwa anak cenderung mencontoh perilaku gurunya. Dalam hal ini guru beusaha mencontohkan perilaku-perilaku yang sesuai dengan tuntunan ajaran islam terutama berkenaan dengan hukum syara. Proses pembentukannya tentu juga didukung oleh orang tua dan lingkungan sekolah serta proses kognitif anak didik.

\footnotetext{
${ }^{18}$ Edward E. Smith and Daryl J. Bem, Fundamentals of Psychology, (USA: Harcourt College Publishers, 2001), h. 299.

${ }^{19}$ Hergenhahn dan Matthew H. Olson. Theories of Learning (Teori Belajar), $\mathrm{h}$. 366.
} 
Hikmatu Ruwaida: Belajar Sosial: Interrelasi Antara Individu, Lingkungan, dan Perilaku Dalam Pembelajaran Fiqih di MI Miftahul Anwar Desa Banua Lawas

Individu merupakan agen kontrol, dimana individu menentukan pengalaman mana yang digunakan dalam melakukan reaksi terhadap kondisi yang ia hadapi. Orang dapat mempengaruhi lingkungan dengan perilaku yang ia lakukan menggunakan model yang pernah mereka dapatkan dan perubahan lingkungan itu pada gilirannya akan dapat mempengaruhi perilaku seseorang. Walaupun ada hubungan yang saling mempengaruhi antara orang, lingkungan, dan perilaku, tetapi pada waktu tertentu salah satu komponen itu akan lebih berpengaruh terhadap komponen yang lain. Keyakinan seseorang merupakan penentu paling berpengaruh terhadap perilakunya. Keyakinan inilah yang disebut dengan self-efficacy yang akan menimbulkan kekuatan positif pada diri seseorang sehingga ia mampu menimbulkan perilaku tertentu.

\section{Pendekatan Perilaku Kognitif dan Regulasi Diri}

Pendekatan perilaku kognitif difokuskan pada agar peserta didik mampu memonitor, mengelola dan mengatur perilakunya sendiri, tanpa bantuan dari luar dirinya. Pendekatan ini berusaha untuk mengubah perilaku anak didik sampai mereka mampu mengevaluasi diri dengan menggunakan keahlian mereka sendiri. ${ }^{20}$ inti dari pendekatan ini adalah seseorang mampu melihat dan merefleksi perilakunya, mengenai salah dan benar maupun baik dan buruknya melalui proses kognitif sehingga pada akhirnya ia mampu mengontrol perilakunya dari hal-hal yang menyimpang.

Regulasi diri sangat penting untuk dimiliki oleh setiap individu. Seseorang dalam kehidupannya merupakan makhluk individu dan makhluk sosial. Regulasi diri menjadi sangat berperan pada saat kita berada pada lingkungan, yang memiliki ragam dan karakter yang bermacam-macam. Tentunya kita harus mampu mengontrol segala tingkah laku kita agar moralitas dan sikap kita tidak menyimpang.

Model yang ditiru yang diamati dan ditiru siswa dapat digolongkan menjadi beberapa kategori yaitu sebagai berikut.

a. Kehidupan nyata, misalnya orang tua di rumah, guru di sekolah dan perilaku masyarakat. Ini yang lebih dominan digunakan di MI Miftahul Anwar.

b. Simbolik. Dalam hal ini adalah model yang digambarkan secara verbal, tertulis atau dalam bentuk gambar. Di MI Miftahul Anwar,

\footnotetext{
${ }^{20}$ John W. Santrock, Psikologi Pendidikan, h. 292-293.
} 
Hikmatu Ruwaida: Belajar Sosial: Interrelasi Antara Individu, Lingkungan, dan Perilaku Dalam Pembelajaran Fiqih di MI Miftahul Anwar Desa Banua Lawas

lambang verbal dan tertulis ini digunakan dalam bentuk cerita, nasihat, yang terkandung dalam pokok-pokok hukum Islam dalam pelajaran Fiqih dan gambar yang digunakan sebagai model belajar bisa berupa gambar praktik shalat, berwudhu, gambaran cara muamalah yang benar dan lain-lain.

c. Represantional, yang mana termasuk dalam golongan ini adalah model yang dipresentasikan dengan menggunakan alat-alat audiovisual terutama televisi dan radio. ${ }^{21}$ Penggunaan jenis-jenis model ini menurut Ibu Norniah selaku guru Fiqih di MI Miftahul Anwar menyesuaikan dengan konten pelajaran, seperti materi adzan, iqamah, zikir, bisa menggunakan audio guna memncontohkan caracara yang baik dan benar.

Jika seseorang mengamati perilaku model, perilaku tersebut akan disimpan dimemorinya. Berpengaruh atau tidak perilaku itu, tergantung pada motivasi pengamat. Apabila menurutnya itu memiliki motif yang kuat dan berguna, misalnya karena ada hadiah, maka ia akan melakukan hal itu, begitu juga sebaliknya. Disinilah pentingnya pembiasaan perilaku yang baik bagi anak usia sekolah dasar sebab dimasa ini, fondasi yang dibangun berupa informasi yang baik akan berguna bagi anak di masa depan.

\section{Implikasi Teori Belajar Sosial dalam Pendidikan}

Teori Bandura mengandung banyak implikasi bagi pendidikan. Bandura percaya bahwa segala sesuatu yang dapat dipelajari melalui pengalaman langsung juga bisa dipeajari melalui pengalaman tak langsung lewat observasi. Model akan amat efektif jika dilihat memiliki kehormatan, kompetensi, status tinggi, atau kekuasaan. Jadi, guru dapat menjadi model yang berpengaruh besar. Melalui perencanaan yang cermat terhadap materi yang akan disajikan, guru dapat lebih dari sekadar menyampaikan informasi rutin. Guru dapat menjadi model untuk suatu keahlian, strategi pemecahan masalah, kode moral, standar performa, aturan dan prinsip umum dan kreativitas. Guru dapat menjadi model tindakan, yang akan diinternalisasikan anak didik dan karenanya menjadi evaluasi diri. ${ }^{22}$

\footnotetext{
${ }^{21}$ Slameto, Belajar dan Faktor-faktor Yang Mempengaruhinya, (Jakarta: Rineka Cipta, 2010), h. 21.

${ }^{22}$ Hergenhahn dan Matthew H. Olson. Theories of Learning (Teori Belajar), $\mathrm{h}$. 385 .
} 
Hikmatu Ruwaida: Belajar Sosial: Interrelasi Antara Individu, Lingkungan, dan Perilaku Dalam Pembelajaran Fiqih di MI Miftahul Anwar Desa Banua Lawas

Oleh karena itu, sebagai seorang guru, sewajarnya memiliki kepribadian yang mantap sebagai bagian dari upayanya untuk menjadi model yang baik bagi anak didiknya. Amat penting bagi seorang guru memberikan contoh yang baik kepada setiap anak didiknya, baik iu model dirinya sendiri maupun jenis model lain yang menunjukkan tingkah laku yang diinginkan dan tugasnya disini adalah membimbing anak didik menuju ke arah yang baik dan positif.

Selain itu, yang harus diperhatikan oleh seorang guru dalam merencanakan pemodelan adalah retensi yang mengandalkan kemampuan verbal anak didik. Bahkan jika sesuatu itu diperhatikan dan telah disimpan, anak didik tidak mungkin tidak mempunyai ketrampilan motorik yang dibutuhkan untuk memproduksi kembali ketrampilan yang telah dipelajari tersebut. Jadi, guru harus mengetahui proses pembentukan perilaku anak didik. Jika anak didik memperhatikan, menyimpan, dan mampu melakukan perilaku yang dipelajari lewat observasi itu, anak didik harus mempunyai insentif (dorongan) untuk melakukan. Disinilah perlunya guru mengetahui proses motivasional. ${ }^{23}$

Guru perlu memastikan dan berusaha menyediakan lingkungan belajar yang kondusif, seperti memberi penguatan moral kepada anak didik secara berkelanjutan, menjelaskan bahwa perilaku bermoral dan tak bermoral memiliki konsekuensi masing-masing. Selain itu, pengajaran seseorang guru hendaknya menarik minat dan perhatian anak didik dan dapat dijadikan acuan untuk diikuti oleh mereka.

\section{Belajar Sosial dalam Perspektif Islam}

Kewajarannya manusia adalah memiliki fitrah meniru sehingga biasanya manusia meniru pola tingkah laku lingkungannya. Namun yang perlu diperhatikan adalah pada proses meniru dalam belajar dan cara memperoleh tingkah laku haruslah dinilai perialaku tersebut apakah akan menimbulkan dampak positif atau negatif pada diri seseorang. ${ }^{24}$

Muhammad Quthb menjelaskan macam-macam metode pendidikan yaitu, salah satunya adalah metode teladan. Sejak fase awal kehidupan manusia banyak sekali contoh individu yang belajar melalui tindakan orang sekitarnya, khususnya dari orang tuanya. Al-Qur'an telah memberikan contoh bagaimana manusia belajar lewat meniru, seperti

\footnotetext{
${ }^{23}$ Hergenhahn dan Matthew H. Olson. Theories of Learning (Teori Belajar), h. 386.

${ }^{24}$ Abdul Aziz el-Quussy, Ilmu Jiwa, (Jakarta: Bulan Bintang: 1976), h. 270
} 
Hikmatu Ruwaida: Belajar Sosial: Interrelasi Antara Individu, Lingkungan, dan Perilaku Dalam Pembelajaran Fiqih di MI Miftahul Anwar Desa Banua Lawas

kisah tentang Qabil yang dapat mengetahui bagaimana menguburkan mayat saudaranya Habil yang telah dibunuhnya, meniru seekor burung gagak yang menggali-gali tanah untuk menguburkan bangkai seekor burung gagak lainnya. Kecendrungan manusia untuk meniru belajar lewat peniruan, menyebabkan ketaladanan menjadi sangat pentingnya dalam proses mengajar. ${ }^{25}$ Metode keteladanan memiliki peranan penting dalam membentuk pribadi manusia, sebab jika keteladanan seorang bapak akan membuat positif bagi pendidikan, jika ia buruk ia buruk maka akan memiliki hasil negatif bagi pendidikan. ${ }^{26}$

Al-Qur'an menjelaskan bahwa keteladanan yang paling baik ada pada Nabi Muhammad saw., dialah yang menjadi panutan dan suri teladan bagi kaum muslimin seluruhnya. Segala sikap dan tingkah laku kaum muslimin pastilah harus mengikuti sikap dan perilaku beliau. Sebagaimana firman Allah.

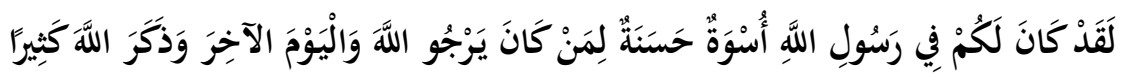

"Sesungguhnya telah ada pada (diri) Rasulullah itu suri teladan yang baik bagimu (yaitu) bagi orang yang mengharap (rahmat) Allah dan (kedatangan) hari kiamat dan Dia banyak menyebut Allah."27

Sayyidah Aisyah pernah ditanya tentang akhlak Rasulullah saw. dan beliau berkata:

\section{كان خُلُقُه القران}

"Akhlaknya adalah al-Qur'an."

Dalam keluarga, orang tua adalah teladan bagi anak-anaknya, oleh karena itu orang tua memiliki kewajiban yang besar untuk memberi teladan yang baik sebagaimana Rasulullah saw. menjadi suri teladan bagi kaum muslimin. Bagaimana pun perilaku orang tua sangat berpengaruh pada perilaku anak. Hal ini karena anak dalam perkembangan hidupnya selalu belajar dengan mengamati apa yang dilakukan orang lain, dalam hal ini yang paling penting adalah orang tua. Melalui cara belajar mengamati (juga disebut "modeling" atau "imitasi/imitation"), anak dengan kemampuan kognitif mereka mengamati perilaku orang lain dan kemudian mengadopsi perilaku itu ke dalam dirinya. Dengan demikian keteladanan menjadi sarana pendidikan yang lebih efektif dari sekadar

\footnotetext{
${ }^{25}$ Mudzakir Ali, Ilmu Pandidikan Islam, (Semarang: PKPI 2 Universitas Wahid Hasyim, 2009), h. 145.

${ }^{26}$ Mudzakir Ali, Ilmu Pandidikan Islam, hlm. 148.

${ }^{27}$ Q.S. al-Ahzab (33): 21
} 
Hikmatu Ruwaida: Belajar Sosial: Interrelasi Antara Individu, Lingkungan, dan Perilaku Dalam Pembelajaran Fiqih di MI Miftahul Anwar Desa Banua Lawas

kata-kata perintah kepada anak-anak tanpa adanya contoh nyata dari orang tua maupun dari guru kepada anak didiknya.

Anwar hundi dalam kitabnya "attarbiyah wa binaul ajyal fi dlauil islam (1975 : 168)" juga menghimbau kepada para pendidik atau guru agar memberikan cpntoh yang baik kepada peserta didik. Didalam praktek pendidikan dan pelajaran metode ini dilaksanakan dalam dua cara yaitu secara direct dan secara non-direct. Secara direct maksudnya bahwa pendidik atau guru itu sendiri harus benar-benar menjadikan dirinya sebagai contoh teladan yang baik kepada peserta didiknya. Sedangkan secara nondirect maksudnya melalui kisah kisah atau riwayat orang-orang besar, para pahlawan, para syuhada, termasuk para nabi. Dengan mengambil kisah-kisah atau riwayat-riwayat yang demikian ini diharapkan peserta didik akan menjadikan tokoh-tokoh ini sebagai uswatuh hasanah. ${ }^{28}$

Lingkungan pendidikan dalam Islam adalah lingkungan alam, kondisi dan situasi dimana pendidikan tersebut berlangsung. Oleh karena itulah, Al-Quran lebih banyak menceritakan dunia pendidikan melalui kisah-kisahnya. Metode keteladanan atau modeling sesungguhnya banyak dijelaskan dalam Al-Quran. Hal tersebut hanya sebagian saja dari metode pendidikan dan pembelajaran yang dikaji dan dianalisis melalui contoh dan isyarat Al-Quran.

\section{Simpulan}

Teori pembelajaran sosial yang dikemukakan oleh Albert Bandura mengindikasikan bahwa manusia dapat berfikir dan mengatur tingkah lakunya sendiri sehingga mereka bukan semata-mata individu yang menjadi objek yang dapat dipengaruhi lingkungan. Manusia itu sendiri pun mampu menciptakan lingkungannya, karena orang dan lingkungan saling mempengaruhi. Belajar merupakan interaksi segitiga yang saling berpengaruh dan mengikat antara lingkungan, faktor-faktor personal dan tingkah laku. Oleh sebab itu juga diperlukan peningkatan self efficacy pada diri anak didik agar yakin bahwa ia dapat mengerjakan dan mendapatkan hasil yang optimal dari apa yang dilakukannya. Sehubungan dengan belajar sosial, guru Fiqih di MI Miftahul Anwar memadukan antara pemodelan, proses kognitif dan lingkungan belajar.

\footnotetext{
${ }^{28}$ Asnelly Ilyas, Mendambakan Anak Shaleh; Prinsip-prinsip Pendidikan Anak dalam Islam, (Bandung: al-Bayan, 1998), h. 39.
} 
Hikmatu Ruwaida: Belajar Sosial: Interrelasi Antara Individu, Lingkungan, dan Perilaku Dalam Pembelajaran Fiqih di MI Miftahul Anwar Desa Banua Lawas

Pemodelan melibatkan guru, orang tua dan melibatkan seluruh warga sekolah. Anak menjadi observator, mengamati sekaligus meniru tingkah laku lingkungan sekolahnya terutama dari gurunya. Dalam proses pengamatan anak melakukan proses kognitif, yang didukung oleh lingkungan sebagai penguat dari tingkah laku tersebut. Orang tua peserta didik sebagai penyokong keberhasilan pembelajaran Fiqih berperan sebagai motivator sekaligus model pula bagi anak.Implikasi belajar sosial dalam Fiqih di Madrasah Ibtidaiyah adalah guru memastikan bahwa ia sendiri menunjukkan tingkah laku yang bisa diteladani serta memberikan penjelasan kepada anak didik berkenaan dengan tingkah laku baik dan buruk, bermoral dan tidak bermoral serta konsekuensinya, oleh sebab itu guru perlu memastikan dan berusaha menyediakan lingkungan sosial yang kondusif.

\section{DAFTAR PUSTAKA}

Ahmadi, Rulam. Metode Penelitian Kualitatif. Yogyakarta: ArRuzz Media, 2014.

Ali, Mudzakir. Ilmu Pandidikan Islam. Semarang: PKPI 2 Universitas Wahid Hasyim, 2009.

Aziz el-Quussy, Abdul. Ilmu Jiwa. Jakarta: Bulan Bintang: 1976.

C. Benson, Nigel, Simon Grove. Psikologi For Beginners. Terj. Medina Chodijah. Bandung: Mizan, 2000.

E. Smith, Edward, Daryl J. Bem. Fundamentals of Psychology. USA: Harcourt College Publishers, 2001.

Hamalik, Oemar. Proses Belajar Mengajar. Bandung: Remaja Rosdakarya, 2013.

Hergenhahn, Matthew H. Olson. Theories of Learning (Teori Belajar). Terj. Triwibowo B.S. Jakarta: Kencana, 2008.

Ilyas, Asnelly. Mendambakan Anak Shaleh; Prinsip-prinsip Pendidikan Anak dalam Islam. Bandung: al-Bayan, 1998.

J. Moeleong, Lexy. Metode Penelitian Kualitatif. Bandung: Remaja Rosdakarya, 2005.

M. Sdorow, Lester, Cheryl A. Rickabaugh. Psychology. New York: McGraw-Hill, 2002.

Nur Ghufron, M., Rini Risnawita S. Teori-teori Psikologi. Yogyakarta: Ar-Ruzz Media, 2014.

Slameto. Belajar dan Faktor-faktor Yang Mempengaruhinya. Jakarta: Rineka Cipta, 2010. 
Hikmatu Ruwaida: Belajar Sosial: Interrelasi Antara Individu, Lingkungan, dan Perilaku Dalam Pembelajaran Fiqih di MI Miftahul Anwar Desa Banua Lawas

Sugiyono. Metode Penelitian Kuantitatif Kualitatif dan $R \& D$. Bandung: Alfabeta, 2012.

W. Santrock, John. Psikologi Pendidikan. Terj. Tri Wibowo B.S. Jakarta: Kencana, 2010. 